\title{
Mali Müşavirler ve Muhasebecilerin Örgütsel Bağlılık Düzeylerinin Demografik Faktörler ile İlişkisi: İstanbul'da Bir Uygulama*
}

\author{
$* * *$

\section{English Relation of Organizational Commitment Levels of Financial Advisors and Accountants with Demographic Factors: An Application in Istanbul}

\author{
Gamze Köseoğlu \\ İstanbul Aydın Üniversitesi, Yüksek Lisans Öğrencisi, gamzelim_34_62@outlook.com \\ ORCID: 0000-0002-4687-7102
}

Özet

Bu çalışmada mali müşavirler ve muhasebecilerin örgütsel bağlılık düzeylerinin demografik faktörler ile ilişkisi analiz edilmiştir. Çalışma İstanbul'da faaliyet gösteren mali müşavirler ve muhasebecilerin örgütsel bağl1lık düzeylerinin demografik faktörler ile ilişkisinin ne düzeyde olduğu araştırılmıştır. Çalışma 100 meslek mensubuna anketin uygulanması sonucunda oluşan veriler analiz edilerek ortaya çıkarılmıştır. Buna göre örgütsel bağlılık ile medeni durum ve cinsiyet arasında bir farklılık veya ilişki bulunmazken diğer demografik faktörler olan aylık kazanç, unvan, tecrübe, unvanda geçirilen süre, yaş ve eğitim durumu ile anlamlı bir ilişki içinde olduğu ve bu faktörler arttıkça örgütsel bağlılık düzeyinin yükseldiği sonucuna varılmıştır.

Anahtar Kelimeler: Mali Müşavir, Muhasebeci, Örgütsel Bağlılık

JEL Sinıflandırması: M10, M12, M14, M19

\begin{abstract}
In this study, the relationship of organizational commitment levels of financial advisors and accountants with demographic factors was analyzed. The study investigated the level of relationship of organizational commitment of financial advisors and accountants operating in Istanbul with demographic factors. The study was created by analyzing the data formed as a result of the application of the questionnaire to 100 professional members. Accordingly, it is concluded that there is no difference or relationship between organizational commitment and marital status and gender, while there is a significant relationship with other demographic factors, monthly earnings, title, experience, time spent in the title, age and educational status, and the level of organizational commitment increases as these factors increase.
\end{abstract}

Keywords: Financial Advisor, Accountant, Organizational Commitment

JEL Classification: M10, M12, M14, M19

\section{GíRiş}

Değişen, gelişen ve büyüyen bir dünyada insanlar birbirleriyle daha fazla temas halindedirler ve bu bağlantıları ekonomik olarak sürdürürler. Bununla birlikte, insanların bu ekonomik ilişkilerini sürdürmek için, ulusal ve uluslararası aracılık yapabilecek kurumlara güçlü bir ihtiyaçları söz konusudur. Öte yandan, bu kurumların, kurum içi ve kurum dışı müşterilerinin memnuniyetini sağlayarak onların sadakatini ve bağl1lığını arttırması gerekmektedir. Bu konuda örgütsel bağl1lık son derece önemlidir.

\footnotetext{
* İstanbul Aydın Üniversitesi, Sosyal Bilimler Enstitüsü, Muhasebe ve Denetim Anabilim Dalında Dr. Öğr. Üyesi Mustafa Özyeşil danışmalığında yürütülen "Mali Müşavirler ve Muhasebecilerin Örgütsel Bağlllık Düzeylerinin Demografik Faktörler ile İlişkisi: İstanbul' da Bir Uygulama” başlıklı yüksek lisans tezinden türetilmiştir.
} 
Finansal yapı içerisinde önemli bir yere sahip olan ve adeta ülkelerin finansal kalbi şeklinde çalışan mali müşavirlik ve muhasebecilik meslek mensuplarının mesleğe bağlllık ve sadakatleri diğer örgütlerde olduğu gibi hayati öneme sahiptir.

Özel sektör ile devlet arasında mali işlerin yürütülmesinde görev yapan mali müşavirlik ve muhasebecilik meslek elemanları yerine getirdikleri görev itibariyle bir yandan devletin memurluğunu yerine getirmekte ve bir yandan da yaptığı tahsilat işlemleri noktasında özel sektörün içinde devletin mali temsilciliğini yapmaktadır. Ancak bu görevi yerine getirirken örgütsel açıdan bazı zorluklarla karşılaşmakta ve bu zorluklar bazen onlarım örgütsel bağlılık düzeylerini düşürebilmektedir. Mali müşavirlik ve musabecilik meslek mensuplarının yaşadıkları zorlukların ve örgütsel bağlılık düzeylerindeki farklılıkların birçok nedeni söz konusu olabileceği gibi, demografik faktörlerle ilişkili olup olmadığ karşımızda durmaktadır.

Mali müşavirlik ve muhasebecilik meslek mensuplarının örgütsel bağl1lık düzeylerinin demografik faktörlerle ilişkisinin ele alınacağı çalışmamızda mali müşavirlik ve muhasebecilik meslek mensuplarının örgütsel bağl1lık düzeylerinin demografik faktörler ile ilşkisi incelenecektir.

\section{KAVRAMSAL ÇERÇEVE}

\section{1. Örgütsel Bağlılık Tanımı ve Kapsamı}

Organizasyonlar, etkileşimde bulunan insanların bir araya gelmesidir ve organizasyonlar, toplumumuzda merkezi bir koordinasyon sistemine benzeyen herhangi bir formasyona sahip en büyük birliklerdir. Organizasyonlar içinde yüksek yapı özgünlüğü ve koordinasyon (organizasyonlar ve örgütlenmemiş kişiler arasında ortak ve değişken ilişkiler) sosyolojik olarak organizmanın sınırlarını bir birim olarak daha iyi çizmektedir (Wiener, 1982: 430).

Örgütsel bağl1lık, bireyin örgütün eylemlerine katılma ve örgütün önem verdiği değerlere güçlü bir inancin sürdürülmesi de dahil olmak üzere örgütün ruhani ilişkisini tanımlayan bir kavramdır (Çetin M. Ö., 2004, s 45).

Bağl1lık; bireyleri, örgütleri ve aralarındaki algılanan uyumu sağlayan bir işlev olarak ifade edilebilmektedir (Çöl, 2004: 48).

Tablo 1. Örgütsel Bağglılığın Gelişim Süreci

\begin{tabular}{|c|c|c|}
\hline Yll & Araştırmacı & Araştırmanın konusu \\
\hline 1956 & Whyte & Örgüte bağl1 işgören ve örgüt için önemi \\
\hline 1958 & Morris ve Sherman & Örgüte bağllllğın değiş̧imsel modeli \\
\hline 1960 & Gouldner & Örgüte bağll1ı̆̆ı güçlendirmek için çalışan ve örgütün karşıllklı iletişimi \\
\hline 1964 & Etzioni & Sosyal ilişkilerin örgüte bağlllık üzerindeki etkisi \\
\hline 1966 & Grusky & Eğitim, cinsiyet ve bağl1lık ilişkileri \\
\hline 1971 & Sheldon & Hedef ve değer bütünlüğünün örgüte bağl1l1k üzerindeki etkisi \\
\hline 1972 & Herbiniak ve Alutto & Cinsiyet ve örgütsel bağlllık ilişkisi \\
\hline 1974 & Porter & Örgüt bağgl1lı̆ına tutumsal yaklaşım modeli. \\
\hline 1975 & Etzioni & Faydacı örgütlerin kötü etkileri \\
\hline 1977 & Salandk & Rol belirsizliği ve örgütsel bağlllık \\
\hline 1978 & Kidron & Güçlü kişisel iş ahlakının örgüte bağlılıkla ilişkisi \\
\hline 1979 & Mowday & Örgüt bağll1lı̆ıına psikolojik olarak yaklaşma \\
\hline 1981 & Morris ve Sherman & Yaş ve kıdemin örgüte bağll1ık üzerindeki etkisi \\
\hline 1982 & Mowday & Örgüt bağlll1k ve süreç modeli \\
\hline 1983 & Rusbult ve Farrell & Örgüt bağl1lık ve yetki modeli \\
\hline
\end{tabular}

(Kaynak: Yağcı 2003: 50) 
Örgütsel bağlılık kavramı bilimsel olarak, kişinin bilinen bir organizasyona karşı duyduğu his, organizasyonla bir duygu ile özdeşleşmesi ve entegrasyon derecesini ifade etmektedir (Arı, 2003:25). Bu açıdan örgütsel bağlılığın iki önemli sorunu vardır. İlk nokta; kişinin örgüt tarafından kabulü ve örgütün amac1 ile bu hedeflere olan güçlü inancıdır. Bu nokta örgütün devamı ve sürekliliği için önem arz etmektedir. İkinci nokta, örgüt için çaba gösterme ve örgütte kalma isteği ve arzusu örgütsel bağlılığın bir göstergesidir. Bu noktadan bakıldığında sayılan özellikler bulunmadığında örgütte bulunan kişilerin örgütle ilgili kurdukları ilişkiler sarsılır ve örgütsel bağlıllık düzeyleri düşmektedir (Balay, 2000: 18). Örgütsel bağl1lık kavramı ile ilgili olarak yapılan önemli çalışmalar kronolojik olarak Tablo 1'deki gibi gösterilebilir.

Literatürde organizasyonda çalışan kişilerin örgüte bağl1lıklarının üç farklı şekilde ifade edildiği belirtilmektedir. Literatürde bunlar; duygusal bağl1lık, devam bağl1lı̆g ve normatif bağl1lık olarak geçmektedir.

Duygusal Bağlılık: Davranışsal bağlılık olarak da bilinen duygusal bağl1lık, örgüt ortamına duygusal tepkilerle yakından ilişkilidir ve daha çok işbirlikçiler tarafından sağlanan memnuniyet, iş ve çalışma taahhüdü ile ilgilidir. Duygusal bağl1lık, işte çalışan bireylerin, kendi tercihleriyle duygusal olarak işte kalma arzusu olarak tanımlanır (Allen ve Meyer 1997). Duygusal bağlılık, örgütte çalışan bireyler tarafından örgütsel amaçların ve değerlerin kabul edilmesini ve örgütün yararına üstün çaba gösterilmesini içerir. Meyer ve Allen, duygusal bağlılıkla en tutarlı ilişkinin iş deneyimleriyle ilgili olduğunu savunuyorlar. Çalışanlar, örgütteki temel ihtiyaçlarını karşılamak için daha az tatmin edici deneyimler yerine, örgüte daha güçlü bir duygusal bağlılık oluşturmalarını sağlayan deneyimlere açıktır. Duygusal bağlılığı olan çalışanlar, örgüte bağlı sadık çalışanlardır. Organizasyonda sürekli güçlü duygusal bağlılıkla çalışan insanlar, ihtiyaç duydukları için değil, istedikleri için organizasyonda kalmaktadırlar (Balay, 2000: 22).

Katılım Taahhüdü (Devam Bağl1lığı): Katılım, örgüte kalmanın ödülleri veya çalışanların örgütten ayrılma kaybı nedeniyle örgütte kalma istekleri ile ilgilidir. Süreklilik taahhüdü, örgütten ayrılma maliyetlerinin farkında olması ve örgütten ayrılma maliyetlerinin yüksek olacağı düşünüldüğünde, üyeliğin devam etmesidir. Bir kişinin örgütteki kalma isteği, örgütteki yatırımlarının toplanmasına, örgütten ayrıldıklarında kaybedeceklerine ve alternatiflerin sınırlı olduğuna bağlıdır. Çalışanın bir örgütteki kıdemi ve faydaları, örgütü bırakma maliyetini yüksek tutarsa, çalışan o örgütle bağlantılıdır. Bu tür bir bağlanmadaki duyguların örgüte bağlanmada küçük bir rol oynadığı düşünülmektedir. Çalışanlarda süreklilik taahhüdüne neden olan bir dizi bireysel ve örgütsel faktör vardır. Katılımı etkileyen bu faktörleri beceri, eğitim, yer değiştirme, bireysel yatırım, emeklilik primi, toplum vs şeklinde sıralamak mümkündür (Başyiğit, 2006: 39-40).

Normatif Bağl1l1k: Örgütteki sadakatin sorumluluğunu ve ahlaki boyutunu oluşturmakta ve çalışanların organizasyonda kalma yükümlülüğünü yansıtmaktadır. Çalışanın örgüte bağlılığı, sosyal sorumluluk bilincine ve örgütte görev alarak kalma algısına bağlıdır. Organizasyonda kalmanın doğru olduğu düşüncesinin bir sonucu olarak, diğer iki taahhüt türünden farklı bir boyutu temsil etmektedir. Çalışanların yüksek normatif bağl11ık duygusuyla örgütte kalmaları gerekmektedir. Bağl1lık duygusu, çalışanların belirli davranış eylemleri gerçekleştirmelerine neden olmakta, çünkü yaptıkları şeyin ahlaki ve doğru olduğuna inanmaktadırlar. Örgütün girişinden önce bireyin sosyalleşme deneyimleri ve örgütün girişini takip eden dönemde örgütsel sosyalleşme deneyimleri normatif bağlılığını etkiler. Çalışmaya başlamadan önce çalışanın deneyimini göz önünde bulundurarak, çalışanın ebeveyni gibi çalışan için önemli kişiler, bireye örgütsel bağlılığın önemini vurguladıysa, çalışanın güçlü bir normatif bağl1lığa sahip olması beklenebilir. Ayrıca, örgütün istihdam başladıktan sonraki süreçte çeşitli örgütsel uygulamalar yoluyla sadakat beklediğine inanılan çalışanlar, örgüte güçlü bir normatif bağl1lığa sahiptir. Normatif bağlılığın temeli, çalışanların örgütte kalmaları için zorunlu hissetmeleridir. Buna göre, çalışanların yaptıklarının örgüte 
bağl1lıklarında ahlaki ve doğru olduğuna inanmaları etkilidir. Bu tür bir taahhüt, çalışanın çalıştı̆̆ organizasyona karşı bir yükümlülügü ve sorumluluğu olduğu ve bu nedenle kendisini organizasyonda kalmak zorunda olduğunu düşündüğü inancına dayanan bir taahhüttür (İnce ve Gül 2005: 19).

Örgütsel bağl1lık kavramından farklı olarak işe bağl1lı kavramı "çalışanın işiyle psikolojik özdeşleşmesinin bilişsel yansıması" olarak tanımlanmaktadır. Başka bir deyişle, çalışanın işinden aldığ memnuniyet ne olursa olsun, çalışmanın çalışma ile zihinsel ve duygusal boyutta entegrasyonunun bir ölçüsü olarak tanımlanabilir. Çalışanın, işle ilgili konularda daha duyarlı olması, içsel olarak işe daha fazla bağlı olması ve zamanının çoğunu çalışmaya adama taahhüdüdür. Diğer bir deyişle, bu insanlar "hayatı işi olan insanlar" değil, "işi hayatı olan insanlar" dır (İnce ve Gül 2005: 17).

Araştırmalarda örgütsel bağl11ık oranı yüksek olan örgütlerde belirlenen hedefe daha hızlı ulaşıldığ ve örgütsel bağl1lığg düşük olan örgütlerde bu oranın daha düşük olduğu görülmektedir. Buna göre örgütsel bağl1lık, örgütler için büyük bir rekabet avantajıdır (İnce ve Gül 2005: 17).

Güçlü ekonomilerden biri olan Japon ekonomisine bakıldığında, örgütlerin birbirleriyle koordineli hareket ettikleri ve bu ekonomik örgütlere bağlı personelin örgütsel bağl1lıklarının yüksek olduğu görülmektedir. Buna göre personelin en yüksek sadakat, maksimum verimlilik ve maksimum sorumlulukta olduğu görülmektedir. Sonuç olarak, yüksek performansl1, eğitimli bir çalışanın örgüte uzun süre katkısını sürdürmesi üretkenlikte bir artış sağlar, çünkü yüksek bir örgütsel bağl1lığı olan çalışan örgütte kalır, organizasyonel hedeflere ulaşmaya çalışır ve düşünmez. (İnce ve Gül 2005: 19).

Örgütsel bağlılık düzeyleri meslektaşlar arasında farklı bir yer tutabilmekte ve meslektaşlarının kendi aralarında belirli ayrımlara gitmesine neden olmaktadır. Bu bağlılık düzeyleri ayrıştırıcı olmamakla birlikte meslek mensubunun örgüte bağl1lık düzeyini de göstermektedir (Doğan ve Kıllı̧, 2007: 57).

Örgütsel bağlılık düzeyleri farklı seviyelerde düşük olan çalışanlarda aşağıda ifade edilen sorunlar ortaya çıkabilmetedir:

- Devamsizlık,

- İşe Geç Kalmak,

- İşe Dikkat Etmemek,

- Düşük Verimlilik,

- İşten Çıkarılma,

- Saldırgan Davranışlar.

Örgütsel bağl1lığı düşük çalışanlar; dedikodu, işi geciktirme ve müşteri memnuniyetini azaltma gibi olumsuz etkiler doğurmakta ve bu hususlar örgütün marka değerini düşürmekte, satış gelirini ve kârını azaltmakdadır (Doğan ve Kılıç, 2007: 57).

Orta düzeyde örgütsel bağl1lığa sahip personel, örgütün amaç ve hedeflerini kabul eder, ancak benimsemek istemez, yani sisteme direnerek kendiliklerini kaybetmek istemezler (Doğan ve Kılıç, 2007: 60). Personel, örgütün istekleri doğrultusunda davranışlar sergilese de örgütün değerleri ve çıkarılarının, kendi değerleri ve çıkarları ile çeliştiğini gördüğünde sorunlar ortaya çıkabilmektedir (Demir ve Öztürk, 2011: 25). Bu, örgütün bütünlüğüne zarar vermektedir.

Yüksek düzeyde örgütsel bağl1lığa sahip personel ise bulunduğu örgütün hedeflerini benimsediği, tüm değerlerini kabul ettiği, örgütüne bağlı olduğu için, örgütü adına herhangi bir fedakarlığı göstermeye uygun bir inanç ve duygu düzeyine sahiptirler.

Örgütsel bağlılık kavramı incelendiğinde üç farklı bakış açısıyla ele alındığı görülmektedir: tutumsal, davranışsal ve çoklu bağlılık. Örgütsel davranış teorisi genellikle örgütsel bağl1lığa tutum açısından yaklaşırken, sosyal psikoloji teorisi örgütsel bağlılığa daha davranışsal yaklaşır (Movday, Steers ve Porter, 1979: 24). 
Tutum yaklaşımı, bağl1lı̆ın duygusal bir yanıt olduğu görüşünü benimserken, davranışçı yaklaşım, bağlılı̆̆ın bireyin geçmiş davranışlarının devamı olduğunu göstermektedir. Bu iki yaklaşımın dışında, konuya farklı bir bakış açısı getiren çoklu taahhüt yaklaşımı, örgütsel bağlılığa üçüncü bir boyut katmaktadır (Aslan, 2008: 170).

Bireyin, personelin, çalışanın, çalışanın veya bir üyenin bir örgüte bağlılığını gösteren birçok kriter vardır. $\mathrm{Bu}$ kriterler aşağıda ayrıntılı olarak açıklanmaktadır.

Kişinin örgüte olan bağl1lığının göstergelerinden biri çalışanın örgütteki ne kadar süre çalıştığıdır. Uzun süredir aynı örgütte çalışıyor olması kişinin örgüte bağlıllğının bir göstergesi olarak düşünülmektedir (Afşar 2011: 16)

O'Reilly ve Chatman (1986) örgütsel bağlılı̆̆ın göstergelerinden birinin, çalışanın örgüt tarafından belirlenen hedefleri kabul ederek bu hedeflere ulaşmaya çalışması olduğunu ifade etmektedirler. Günümüzde özellikle imalatçı örgütler için bu hususun önemli olduğu görülmektedir. Çalışanın, örgütün hedeflerini benimsemesi, aynı örgütteki varlığını sürdürmek istediği şeklinde değerlendirilmektedir (Erdoğan 1996: 5).

Araştırmalar örgütsel bağlılığın, çalışanların ortaya koyduğu, örgütün değer ve hedeflerini kabul etme ve örgütün yararına ek çaba gösterme gibi bir takım örgütsel davranış ve tutumlarla ilişkili olduğunu göstermektedir (Gül 2002: 38). Örgüte yüksek ve düşük bağll1ık duyan bireylerin bağl1lık düzeyleriyle ilişkiki olarak bir takım kazanım ve kayıpları da sözkonusu olmaktadır.

Yüksek bağl1lık, ücret artışı, erken terfi ve ödüller şeklinde karşılık bulurken; örgüte zayıf bağl1lık, maaş artışı ve terfinin askıya alınması ve cezalandırmalar şeklinde karşılık bulmaktadır. Personelin örgütle özdeşleşmesi ve görüşlerini benimsemesi örgütün amaçlarından kaynaklanmaktadır. İçinde bulundukları örgüte duygusal olarak bağlı çalışanlar, örgütün üyesi olmaktan mutluluk duyarlar. Duygusal bağl1lığı güçlü olan çalışan örgütte kalmaktadır (Allen ve Meyer 1990: 16).

\section{LITERATÜR TARAMASI}

Literatür incelendiğinde örgütsel bağl1lık hakkında yazılan Türkçe ve İngilizce yüksek lisans tezi sayısı 1099, doktora tezi sayısı 167'dir. Ayrıca, birçok yabancı dilde ve Türkçe yazılmış binlerce makale, seminer ve makale bulunmaktadır.

Ulusal alanda yapılan çalışmalarda "örgütsel bağl1lık” kavramının iki özelliği vurgulanmıştır. Bağlılık; "Bireyin kendisini örgütteki diğer insanlara yakın olma hissi ile ifade ettiği kimlik boyutu ve araçsal bir ilişkiyi tanımlayan uyum boyutunu içeren daha genel bir kavramdır (Balay 2000: 18).

Diğer araştırmalar bu kavramı "örgüte bağlılık” olarak kullanmıştır. Personelin örgüte bağl1lı̆̆ örgütsel taahhüttür. Birey bir organizasyonda üstlendiği rolleri yerine getiriken diğer personel, çalışma ekipleri ve çalıştığı organizasyonun iklimi ile de etkileşime girer. Örgüt içindeki davranışlarını "sosyal organizasyonel davranış" olarak adlandırmak mümkündür. Bu davranışlar, bireylerin örgütteki diğer bireylerle birlikte kaldıkları süre boyunca, birlik ve bütünlük sağlamak için sergilediği eylemlerdir. Profesyonel sosyal örgütsel davranış "tanımlanmamış rol davranışı" ve "tanımlanmış rol davranışı" olarak 2 başlık altında ele alınmaktadır. Tanımlanamayan rol davranışları; resmi rol tanımlarında yer almayan olumlu sosyal davranışlardır. Belirtilenin dışında örgütün yararına bireyin faaliyetidir. Tanımlanan rol davranışı; bir işin parçası olarak gerçekleştirilen davranışlardır. Ayrıca rol tanımlarında belirtilen çalışma davranışı özelliklerini de yansıtmaktadır (Özsoy, Ergül ve Erkekik 2004: 45).

Altıöz, Çöp ve Sığındı tarafindan 2011 yılında yapılan araştırmada, personelin örgütsel bağlılı̆̆ı ile örgütsel sinizm arasındaki ilişki incelenmiştir. Araştırma, otel çalışanı olan 210 kişilik bir örneklem grubu kapsamaktadır. Araştırma sonucunda; örgütsel bağlılığı yüksek çalışanların daha az alaycı tutum 
sergiledikleri, örgütsel bağl1lıkları düşük olanların ise nisbeten daha yüksek oranda alaycı tutum sergiledikleri bulgusuna ulaşılmıştır (Altınöz, Çöp ve Sığındı 2011: 290).

Fındık ve Eryeşil (2012) tarafından "demir-çelik" sektöründe çalışanlar üzerinde yapılan çalışmada, örgütsel bağl1lık ile örgütsel sinizm arasında ne tür bir ilişki olduğu araştırılmış ve örgütsel bağl1lık ile örgütsel sinizm arasında negatif yönlü güçlü bir ilişki bulunmuştur (Fındık ve Eryeşil. 2012: 253)

2007 yılında Bernerth'in arkadaşları ile yapılan araştırmaya göre, araştırmaya katılan 117 gönüllü katılımcı üzerinde yapılan örgütsel bağlılık testinde örgütsel bağlılık ve sinizm arasında pozitif bir ilişki vardır. (Bernert ve ark. 2007: 305).

Barnes tarafından 2010 yılında yürütülen doktora çalışmasında örgütsel bağl1lık ve örgütsel sinizm arasındaki ilişki ve bu iki değişkenin örgütsel vatandaşlık davranışları üzerindeki etkisi incelenmiştir. Araştırma 473 kişilik bir grupla yürütülmüştür. Araştırmada örgütsel bağlılık düzeyi ile çalışanların örgütsel sinizm algısı arasında negatif yönlü bir korelasyon olduğu bulgusuna ulaşılmıştır (Barnes 2010, $50)$.

2013 'te Nafei ve Kaifi 297 kişiyle yürüttükleri araştırmalarında örgütsel bağl1lık ve sinizm ilişkisini incelemişlerdir. Yüksek örgütsel sinizm düzeyine sahip çalışanların düşük örgütsel bağl1lık düzeyine sahip oldukları bulgusuna ulaşmışlardır (Nafei ve Kaifi 2013: 136).

\section{YÖNTEM}

Mali müşavir ve muhasebecilerin içinde bulunduğu finansal örgüte bağl1lık düzeylerinin ölçüldüğü çalışmamızda analizler SPSS v.26 kullanılarak yapılmıştır. Veriler anket yoluyla elde edilmiş ve istatistiksel analizler kullanılarak irdelenmiştir. Çalışmada kullanılan anket Gökburun (2017)'un çalışmasından uyarlanmıştır1. Araştırmada örgütsel bağl1lığı ölçmek için kullanılan anket 18 ifadeden oluşmaktadır. İfadelerin değerlendirilmesinde 5'li Likert Ölçeği kullanılmıştır. Anket demografik faktörlerin ölçüldüğü ifadeler de dahil olmak üzere toplamda 26 ifadeden oluşmaktadır. Örgütsel bağl1lık ile ilgili ifadeler aşağıdaki gibidir:

1. Kendimi bu büroda yabancı biri gibi hissediyorum.

2. Bulunduğum kuruma karşı kendimi minnettar hissediyorum.

3. Büroda yaşanan sorunları kendi sorunlarımı çözer gibi çözerim.

4. Bu meslek sadakatime layıktır.

5. Muhasebecilik mesleği benim için büyük bir önem arz ediyor.

6. Şimdi bu meslekte şu an çalışıyor olmam çok isekli oluşumdan değil bilakis zorunlu olduğumdan kaynaklanmaktadır.

7. Meslekten ayrilmak istemiyorum.

8. Bu mesleğe ve muhasebeciler ile duygusal aramda olarak hiçbir bağım yoktur.

9. İşimden şimdi ayrılmak istiyorum fakat buradaki ortamdan dolayı kendimi buradaki iş arkadaşlarına karşı sorumluluk altında hissediyorum.

10. Eğer staj gibi zamanımı alan bir şey için emek vermemiş olmasaydım buradan şimdi ayrılmıştım.

11. Eğer muhasebecilik mesleğinden ayrılırsam iş alternatifinin az olmasından dolayı zorlanırım.

12. Muhasebeci olarak çalışmam için herhangi bir zorunluluğum yok.

13. Kendim için uygun bir iş firsatı doğması karşısında muhasebecilik mesleğinden ayrılmayacağım çünkü bu mesleğe karşı bu davranış uygun bir davranış değildir.

14. Muhasebecilik mesleğinden şimdi ayrılmam durumunda suçluluk psikolojisine girerim.

15. Eğer muhasebecilik mesleğinden ayrılırsam hayatım alt üst olur.

\footnotetext{
${ }^{1}$ Gökburun, H. (2017). Örgütsel Bağllıı ve Banka Çalışanları: İstanbulda Bir Uygulama. Yüksek Lisans Tezi, İstanbul: Beykent Üniversitesi Sosyal Bilimler Enstitüsü.
} 
16. İş hayatımın geriye kalan kısmını da muhasebeci olarak geçirmek istiyorum.

17. Bu meslekten ayrılmam konusunda çok az tercihim olduğunu düşünüyorum.

18. Kendimi bu mesleğe ait hissediyorum.

Evren olarak İstanbul'da faaliyet gösteren serbest muhasebeciler, serbest muhasebeci mali müşavirler ve yeminli mali müşavirler seçilmiştir. Türkiye'de ve İstanbul'da bulunan Serbest Muhasebeci ve Mali Müşavirler Oda'larına ait toplam üye sayıları Tablo 2'deki gibidir.

Tablo 2. Türkiye'de ve İstanbul'da odalara kayıtlı meslek mensupları

\begin{tabular}{llll}
\hline Oda Adı & SM Sayısı & SMMM Sayısı & Toplam Sayı \\
\hline $\begin{array}{l}\text { İstanbul SMMMO } \\
\text { Türkiye Geneli (ISMMO Dahil) }\end{array}$ & 2073 & 40538 & 42611 \\
Toplam & & & \\
\hline
\end{tabular}

(Kaynak: Akdemir (2019: 1)

Yukarıda görüldüğü üzere Türkiyede Serbest Muhasebeci Mali Müşavirler odasına kayıtlı toplam çalışan sayıs1 108125 dir. Örneklem grup İstanbul Serbest Muhasebeci Mali Müşavirler Odasına kayıtl1 42611 kişiden oluşan evren içerisinden seçilmiştir. Toplam dağıtılan anket sayısı 214 tür. Dağıtılan 214 anketten

123 adet geri dönüş sağlanmıştır. Ancak eksik ve özensiz doldurulan, araştırmanın güvenilirlik ve geçerliliğini etkileme sorunu doğurabilecek anketler değerlendirmeye alınmamış, çalışma analiz için uygun görülen 100 adet anket ile yürütülmüştür. Örneklem büyüklüğünün bulunmasına ilişkin aşağıdaki formül kullanılmıştır:

$n=\frac{n_{0}}{1+\frac{n_{0}-1}{N}}$

$$
\mathrm{n}_{0}=\frac{\left(\mathrm{t}^{2} \mathrm{PQ}\right)}{\mathrm{d}^{2}}
$$

• $\mathrm{N}$ evren büyüklüğü,

- $\mathrm{t}$ güven düzeyine karşıllk gelen tablo değerini,

- d tahmini tolerans miktarıdır.

- PQ evren için tahmin edilen varyans,

- P belli bir özelliğe sahip olma, Q ise olmama durumudur

Örneklem grubun belirlenmesinde, küme örnekleme yöntemi kullanılmıştır. Küme örneklemede evren birey-birimler yerine kümelere ayrılmaktadır. Evren genişliği çok büyük ve birimler geniş bir coğrafi alana yayılmış olduğunda örneklemin evrendeki birimlerden basit rastgele seçim yöntemi yaparak değil de bu birimlerden oluşturulan gruplardan rastgele seçim yapmak suretiyle oluşturulması daha etkili olmaktadır (Kılıç, 2013: 45-46).

\section{ANALIZ ve BULGULAR}

Ölçeğin güvenilirliğini analiz etmek için içsel tutarlılık ölçütü olan Cronbach $\alpha$ katsayısına bakılmıştır. Cronbach $\alpha$ değeri 0,712 $(\alpha>0.60)$ olarak bulunmuştur. Cronbach $\alpha$ değerinin, yüksek bir güvenilirlik düzeyine işaret ettiği görülmektedir.

Verilerin faktör analizine uygunluğu için Kaiser-Meyer-Olkin (KMO) Örneklem Yeterliliği Ölçütü ve Barlett'in Küresellik Testi kullanılmıştır. Elde edilen değerler verilerin faktör analizi uygulamaya müsait olduğunu göstermiştir. Yapılan faktör analizi sonucunda anketteki ifadelerin faktör yükleri açısından yeterliliğe sahip oldukları görülmüştür. Analizde T testleri ve ANOVA testleri kullanılmıştır. 
Araştırma için temel kısıtların; zaman kısıtı, yanıtlayıcıların genel ruh halleri ile değilde anlık psikoloji ile yanıt verme ihtimallerinin var oluşu ve örneklem sayısının büyük olan evren için nispeten az oluşu olduğu söylenebilir.

Örneklem gruba ait ulaşılan demografik bulgular aşağıda yer alan Tablo 3’teki gibidir.

Tablo 3. Demografik bulgular

\begin{tabular}{|c|c|c|c|c|c|}
\hline Değiş̧kenler & Frekans & Yüzde (\%) & Değişkenler & Frekans & Yüzde (\%) \\
\hline Medeni Durum & & & Cinsiyet & & \\
\hline Evli & 52 & 52 & Erkek & 57 & 57 \\
\hline Bekâr & 48 & 48 & Kadın & 43 & 43 \\
\hline Toplam & 100 & 100.0 & Toplam & 100 & 87,0 \\
\hline Yaş & & & Ĕ̈itim Durumu & & \\
\hline $18-30$ & 39 & 33,9 & Önlisans & 11 & 9,6 \\
\hline $36-40$ & 26 & 22,6 & Lisans & 63 & 54,8 \\
\hline $46-50$ & 19 & 16,5 & Lisansüstü & 26 & 22,6 \\
\hline 56 ve Üstü & 1 &, 9 & Total & 100 & 87,0 \\
\hline Toplam & 100 & 100 & Hizmet Süresi & & \\
\hline Unvanınız & & & 4 yildan az & 24 & 20,9 \\
\hline SMMM & 42 & 36,5 & 4-7 Y1l & 21 & 18,3 \\
\hline YMMM & 16 & 13,9 & 8-11 Yil & 33 & 28,7 \\
\hline Muhasebe Elemanı & 26 & 22,6 & 12 Yıl ve Üzeri & 22 & 19,1 \\
\hline Ön Muhasebe Elemanı & 15 & 13,0 & Total & 100 & 87,0 \\
\hline Toplam & 100 & 100 & Aylık Gelir & & \\
\hline Tecrübe & & & $5,000-10,000 €$ & 65 & 56,5 \\
\hline $1-5$ y1l & 19 & 16,5 & 10,001-15,000€ & 11 & 9,6 \\
\hline 6- 10 Y1l & 40 & 34,8 & 15,001-20,000€ & 24 & 20,9 \\
\hline 21 Y1l ve Üzeri & 17 & 14,8 & Toplam & & \\
\hline Total & 100 & 100 & & & \\
\hline
\end{tabular}

Tablodanda görüldüğü üzere örneklemin \%57'sini erkekler \%43'ünü ise kadınlar oluşturmaktadır.

Ankete katılan meslek mensuplarının \%63'ü lisans mezunudur. Buna göre lisans mezunlarının çok olması bu mesleğin tercih edilebilirlik yönünden daha fazla rağbet gördüğü anlamı taşımaktadır. Ankete katılanların \%26'sı ise lisansüstü mezunudur. Bu da ankete katılan meslek mensuplarının ilgili yasaya göre hem staj sürelerini kısaltmaları hem de kariyerlerinde ilerleme yapabilmeleri için ve teknik donanımlarını geliştirmeleri için bu eğitim seviyelerini seçtikleri anlamına gelmektedir.

Ankete katılanların \%33'ünün 8-11 yıl arası çalıştıkları görülmektedir. Bu seçeneği seçen meslek mensuplarının staj ile birlikte 8-11 yıl arası çalışmış oldukları tahmin edilmektedir. Çünkü staj süresi 3 yıldır. Fakat ilgili kanuna göre yüksek lisans mezunları için bu süre 2 yıla düşebilmektedir.

Ankete katılanların \%65'inin aylık geliri 5.000-10.000 £ aralığında olduğu görülmektedir. Bu sonuca göre ankete katılan bu meslek mensuplarının meslekte ilk yılları olduğu ve kazançlarının ilk yılları olmaları hasebiyle bu şekilde olduğu yorumu yapılabilir.

Aylık geliri 10.001-15.000 € olan meslek mensuplarının katılım oranı ise \%11'dir. Bu meslek mensuplarının ise mesleklerinde daha tecrübeli oldukları söylenebilir. Yılar geçtikçe kazanılan güven 
sonucu bu meslek mensuplarının vergi mükelleflerinin güvenkelerinikazandıkları ve bu meslek mensuplarının tercih edilmeye başlandığı söylenebilir.

Muhasebe meslek mensupluğunu en fazla icra eden ve en fazla tecrübeye sahip olanların ankete katılanların \%17'sini oluşturdukları yani 21 yıl ve üzeri muhasebe meslek mensubu oldukları görülmektedir. Buna göre ankete katılan meslek mensuplarının \%17'si YMMM düzeyinde veya bu meslekte uzun yıllar muhasebe elemanı olarak çalışmış personelden veya uzun yıllar SMMM olarak bu mesleği icra etmiş olan meslek mensuplarından oluşmaktadır.

Muhasebe meslek mensuplarının örgütsel bağl1lık düzeyleri ile demografik özellikleri arasında anlamlı bir ilişkinin var olup olmadığını ölçmek için t testleri ve anova testleri yapılmıştır. Araştırmaya ilişkin oluşturulan hipotezler aşağıdaki gibidir. Bunlar:

H0: Muhasebe meslek mensuplarının örgütsel bağlılıkları ile demografik faktörleri arasında anlamlı bir farkl111k YOKTUR.

H1: Muhasebe meslek mensuplarının örgütsel bağlılıkları ile demografik faktörleriarasında anlamlı bir farklı11k VARDIR.

Hipotez test sonuçları Tablo 4'de verilmektedir

Tablo 4. Hipotez Test Sonuçları

\begin{tabular}{lcccc}
\hline Değişkenler & $\boldsymbol{\beta}$ & $\mathbf{R 2}$ & t -Değeri & Sonuç \\
\hline Örgütsel Bağl1lık - Medeni Durum (H1) & $.997^{*}$ & .336 & 0,003 & Red \\
Örgütsel Bağl1lık - Unvan (H1) & $.000^{*}$ & .204 & 1,166 & Kabul \\
Örgütsel Bağl1lık - Yaş (H1) & $.000^{*}$ & .230 & 2,274 & Kabul \\
Örgütsel Bağl11ık - Eğitim (H1) & $.000^{*}$ & .265 & 0,729 & Kabul \\
Örgütsel Bağl1lık - Eğtim Düzeyi (H1) & $.000^{*}$ & .943 & 1,780 & Kabul \\
Örgütsel Bağl1lık - Unvanlarda Geçirilen Süre (H1) & $.000^{*}$ & .150 & 0,811 & Kabul \\
Örgütsel Bağl1lık - AylıGGelir (H1) & $.000^{*}$ & 1,034 & 4,077 & Kabul \\
Örgütsel Bağl1lık - Cinsiyet (H1) & $.010^{*}$ & .283 & 1,548 & Red \\
Örgütsel Bağl1lık - Tecrübe (H1 & .000 & .325 & 3,652 & Kabul \\
\hline
\end{tabular}

${ }^{*} \mathrm{p}<0,05$

Örgütsel bağlılık ile medeni durum arasındaki ilişki incelendiğinde örgütsel bağlılık açısından evli veya bekâr olmanın herhangi bir öneminin olmadığı sonucuna varılmıştır. Analiz sonucunu genelleştirilecek olursa muhasebe meslek mensubu olmanın medeni durumla herhangi bir bağlantısının olmadığı ve medeni durumun meslek mensubu olmak ile ilgili herhangi bir şey ifade etmediği söylenebilir. Örgütsel bağl1lık daha çok başka faktörlerin etkileşimi sonucunda ortaya çıkan bir olgudur. Buna bağlı olarak örgütsel bağlılık ile medeni durum arasında herhangi bir ilişki yoktur.

Örgütsel bağlılık ile cinsiyeti "erkek" olan meslek mensuplarının örgütsel bağl1lı̆̆ ile cinsiyeti "kadın" olan meslek mensuplarının örgütsel bağl1lık ile aralarında anlamlı bir farklılığın $p<0,05$ düzeyinde istatistiksel olarak anlamlı olmadığını söyleyebiliriz. Medeni durum ile muhasebe meslek elemanının örgütsel bağlılık düzeyi arasında ilişki olmadığı gibi muhasebe meslek mensubunun örgütsel bağl1lığının cinsiyetle de herhangi bir ilişkisi olmadığ 1 ve cinsiyetin meslek mensubu olmak ile ilgili herhangi bir şey ifade etmediği sonucuna varılmıştır. Örgütsel bağlılık daha çok başka faktörlerin etkileşimi sonucunda ortaya çıkan bir olgudur. Buna bağlı olarak örgütsel bağlılığın medeni durum ve cinsiyet ile arasında herhangi bir ilişki yoktur. 
Unvan ile örgütsel bağl1lık ilişkisi incelendiğinde, unvanlarda yükselme meydana geldiğinde örgütsel bağl1lık düzeyinin arttığ 1 ve buna bağlı olarak da örgüte olan güvenin de arttığ1 görülmektedir. Buna göre muhasebe meslek mensubu olan ve unvanlarında yükselerek SMMM, YMM olan meslek mensuplarının örgütsel bağlılık düzeyleri daha yüksektir. Bunu muhasebe elemanları ve ön muhasebe elemanları takip etmektedir. Bu da özetle muhasebe meslek mensubu olan ve unvanlarında en yüksek dereceye sahip olan muhasebe meslek mensuplarının örgütsel bağlılık düzeyi daha yüksektir.

18-30 yaş aralığında olanlar ile 56 ve üstü yaş aralığında olan meslek mensuplarının örgütsel bağlılık düzeyleri düşüktür. Genç ve muhasebe meslek elemanı olmak isteyen biri ile artık belli bir tecrübe edinmiş ve emeklilik yolunda kendisini rahatlatmak isteyen bir meslek mensubunun örgütsel bağlllık düzeylerinin benzer biçimde düşük olduğu görülmüştür.

Diğer yaş gruplarına bakıldığında özellikle 46-50 yaş aralığı ile 31-35 yaş aralığında olan meslek mensuplarının örgütsel bağl1lık düzeylerinin yüksek olduğu görülmektedir.

$\mathrm{Bu}$ da meslekte verilen emeğin karşılı̆̆ının alındığı yaşlarda örgütsel bağlılığın yüksek olduğu, mesleğinde emekli olma noktasına gelmiş veya mesleğe daha yeni adım atmaya başlamış genç kesimde örgütsel bağlılık düzeyinin düşük olduğu sunucuna varılmıştır.

Eğtim düzeyi ile örgütsel bağlılık arasındaki ilişki incelendiğinde eğitim düzeyi yükseldikçe örgütsel bağlılık düzeyinin de arttığı görülmüştür. Analiz sonuçlarına göre önlisans mezunu meslek mensubunun lisans mezunu bir meslek mensubuna göre örgütsel bağlllık düzeyi daha düşüktür. Buna göre lisans mezunu ile lisansüstü mezun bir meslek mensubu arasında örgütsel bağl1lık düzeyi açısından büyük bir farklılık vardir.

Muhasebe meslek mensuplarının unvanlarında (SMMM, YMM) geçirdikleri hizmet sürelerine göre örgütsel bağlılıklarında farklılaşma olup olmadığı analiz edildiğinde, 4 yıldan az bu mesleği icra etmiş olan meslek mensuplarında örgütsel bağl1lık düzeyi en düşükken, 12 yıl ve üzeri bu meslekte bir unvanla icra eden SMMM ve YMM'lerin örgütsel bağl11ık düzeyleri artmaktadır. Diğer yandan bakıldığında ise, 4-7 yıl arası çalışanların örgütsel bağl1lık düzeyi ile 8-11 yıl arası çalışanların örgütsel bağl1lık düzeyleri de 4 yıldan az süredir mesleği icra edenlere kıyasla daha yüksektir. Yalnızca yukarıdaki tablo ele alındığında ise sonuç olarak unvanda geçirilen hizmet y1lı arttıkça örgütsel bağl1lık düzeyi artmaktadır sonucuna varılmıştır.

Yapılan analizler sonucunda meslek mensuplarının kazançları arttığında örgütsel bağlılıklarına ilişkin ortalamalarının da arttığı görülmüştür. Buna göre 5.000-10.000 € arasında kazanan meslek mensupları ile 15.001-20.000 € arasında kazanan meslek mensuplarının örgütsel bağlılık düzeyleri birbirinden farklıdır. 5.000-10.000 € arasında kazanan meslek mensubunun örgütsel bağl1lık düzeyi 15.001-20.000 €arasında kazanan meslek mensubundan daha düşüktür. Öte yandan 10.001-15.000 € arasında kazanan meslek mensuplarının örgütsel bağlılık düzeyi 5.000-10.000 € arasında kazanan meslek mensubundan daha yüksekken 15.001-20.000 € arasında kazananlardan daha düşüktür. Genel anlamda meslek mensuplarının kazanç durumları ile örgütsel bağlılık düzeyleri arasında pozitif yönlü anlamlı bir ilişki sözkonusudur. Aylık kazanç arttıkça örgütsel bağlılık düzeyi de artmaktadır.

Yapılan analizler saucunda örgütsel bağl1lık düzeyinin tecrübeye göre artış gösterdiği görülmüştür. Bu da tecrübenin örgütsel bağl1lık açısından önemi olduğunu, örgütsel bağl1lık düzeyi ile meslek mensuplarının tecrübeleri arasındaki ilişkinin anlamlı olduğunu göstermektedir. Tecrübe arttıkça meslek mensuplarının zor ve sıkıntılı işlemlerde daha az zorlanacakları ve bu aşamaları zorlansalarda geçecekleri aşikârdır.

\section{SONUÇ}

Yapılan araştırma sonucunda mali müşavirler ve muhasebecilerin örgütsel bağlılık düzeyleri ile demografik yapıları arasında ilişkiler incelenmiş ve aşağıdaki sonuçlara ulaşılmıştır: 
- Meslek mensuplarının cinsiyetlerine göre örgütsel bağl1lık düzeyleri arasında bir farklılık olup olmadığı incelenmiş ve bir farklılık olmadığı sonucuna ulaşılmıştır. Meslek mensuplarının cinsiyetlerine göre örgütsel bağlllık düzeyleri arasında bir farklılık olup olmadığı incelenmiş ve bir farklılık olmadığı sonucuna ulaşılmıştır.

- Meslek mensuplarının medeni durumlarına göre örgütsel bağlılık düzeyleri arasında bir farklılık olup olmadığı incelenmiş ve bir farklılık olmadığı sonucuna ulaşılmıştır.

- Meslek mensuplarından 18-30 yaş aralığında bulunanların liseden yeni mezun veya önlisans eğitim düzeyine sahip olan kişilerden oluştuğu ve 36-40 yaş aralığında olanların ise meslekte uzun zaman harcadıkları ve emek verdikleri sonucuna varılmıştır.

- Özellikle lisans mezunlarının, ilgili yasalara göre, hem staj sürelerinin diğer adaylara göre kısa olması avantajı sağlamasından dolayı hem de kariyerleri ve teknik donanımlarını geliştirmeleri için uygun bir alan olarak görmelerinden dolayı mesleğe yoğun bir rağbet gösterdikleri sonucuna varılmıştır.

- Mesleğe girenlerin gerek SMMM olarak gerekse YMMM olarak uzun yıllar bu mesleği sürdürdükleri sonucuna varılmıştır. Bu durum meslekte geçirilen sürenin artmasının örgüte ve mesleğe duyulan sevgiyi arttırması ile ilişkillendirilebilir.

- Meslek mensuplarının unvan durumlarına göre örgütsel bağlılık düzeyleri arasında bir farklılık olup olmadığ incelenmiş ve unvanlar yükseldiğinde örgütsel bağlllık düzeylerinin yükseldiği sonucuna varılmıştır. Meslek mensubunun unvanında meydana gelen bir yükselmede meslek mensubunun örgütsel bağlılık düzeyinin daha fazla yükselmesinin sebebi mesleğe girişte yaşanılan zorlukların tekrar yaşanmayacağı kanısına varması ve bu şekilde hem meslek bağlılığının hem de örgütsel bağl1lık düzeyinin yükseldiği söylenebilir.

- Meslek mensuplarının yaşlarına göre örgütsel bağlılık düzeyleri arasında bir farklılık olup olmadığ1 incelenmiş ve genç yaşta olanlar ile daha yaşlı olanların örgütsel bağlılık düzeylerinin daha yüksek olduğu sonucuna varılmıştır. Yaşın muhasebe meslek grubunda önemli olduğu ve yaşı genç olanların mesleğe yeni girdiklerinde daha şevkli oldukları için örgütsel bağlılık düzeylerinin daha yüksek olduğu söylenebilir. 56 yaş ve üzerinde olanların mesleğe bağlllık düzeylerinin daha yüksek olması durumu, meslekte tecrübe kazanmış olmaları ve yaş ile beraber iş tecrübesinin meslekte uzmanlık kazandırması ile ilişkilendirilebilir. Genç ve yaşı meslek mensupları arasında kalan grupta bulunan meslek mensuplarının örgütsel bağlılık düzeylerinin nispeten düşük olmasının nedeni ise tükenmişlik veya bıkkınlık ile ilişkilendirilebilir.

- Meslek mensuplarının eğitim düzeylerine göre örgütsel bağl1lık düzeyleri arasında bir farklılık olup olmadığı incelenmiş ve meslek mensuplarının eğitim düzeyi arttıkça örgütsel bağl1lıklarının da yükseldiği bulgusuna ulaşılmıştır. Bunun başlıca nedeni eğitim düzeyi yükseldikçe meslekte unvan olarak daha hızlı yükselme şansını vermesidir.

- Örgütsel bağl1lık düzeyinin katılan meslek mensuplarının hizmette geçirdikleri süreye göre ilişki düzeyinin olup olmadığı incelendiğinde, mesleğe yeni girmiş meslek mensuplarının örgütsel bağl1lık düzeylerinin düşük olduğu buna karşıllık ise hizmet yılı artan meslek mensuplarının örgütsel bağl1lık düzeylerinin daha yüksek olduğu sonucuna varılmıştır. Bunun nedenin mesleğe yeni girmiş bir meslek mensubunun mesleğin zorluklarını görmesi ve bundan dolayı şevklerinin kırılması sebebiyle örgütsel bağlılık düzeylerinin düştüğü, hizmet yılı uzadıkça hizmet sırasında oluşabilecek sorunlarının çözümünde daha tecrübelerin artması sonucunda da örgütsel bağlılık düzeylerinin yükseldiği söylenebilir.

- Meslek mensuplarının kazandıkları ücret düzeylerine göre örgütsel bağl1lık düzeyleri arasında bir farklılık olup olmadığı incelenmiş ve meslek mensuplarının ücretleri arttıkça örgütsel bağlılıklarının da arttığı bulgusuna ulaşılmıştır. Bu durum ücretin meslek mensubunun işinde 
motivasyon kaynağı olduğu ve bunun artması durumunda örgütsel bağl1lık düzeyini yükselttiği şeklinde yarumlanabilir.

Yukarıdaki sonuçlar göz önüne alındığında Arı ve Ergeneli (2003)'nin psikolojik güçlendirme algısı ile bazı demografik değişkenlerin örgütsel bağl1lık üzerindeki etkisini belirlemeye çalıştıkları çalışmada, örgütsel bağl11ıkla cinsiyet, yönetsel pozisyon, ve çalışma süresinin ilişkisinin olduğu ancak eğitim düzeyinin ilişkisinin olmadığı sonucuna varılmıştır. Yapılan bu çalışma ile bizim çalışmamızda örgütsel bağlılık ile eğitim düzeyi arasındaki ilişkinin farklı çıkmasının sebebi meslek gruplarının farklı olması ve eğitim düzeylerinin bulundukları meslekte yükselmede bir basamak olarak kullanılamaması veya mesleki gelişime herhangi bir katkısının olmaması ile açıklanabilir.

Bozkurt ve Yurt (2013) yapmış oldukları araştırmalarında, çalışma süresi açısından normatif bağlılığın, akademik ünvana göre devam bağlılığının, yaş açısından duygusal bağlılığın ve normatif bağlılığın, medeni duruma göre duygusal bağlılı̆̆ın anlamlı bir farkl1lığa sahip olduğu bulgusuna ulaşırken, cinsiyet ve eğitim açısından örgütsel bağl1lı̆̆ı anlamlı bir farklılığa sahip olmadığı bulgusuna ulaşmışlardır. Bizim çalışmamızda ise Bozkurt ve Yurt (2013)ün çalışmasından farklı olarak medeni durumun örgütsel bağlılık açısından anlamlı bir farklılık ortaya çıkarmadığı bulgusuna ulaşılmıştır.

Genel anlamda bakılacak olursa örgütsel bağlılıkla ilgili yapılan çalışmalarda, farklı organizasyon yapılarında çalışılması, içinde bulnunulan örgüt iklimi gibi nedenlerin örgütsel bağlılık üzerinde etkili olduğu görülmüştür. Örgütsel bağlılık ile ilgili yapılacak araştırmalarda araştırmacıların aşağıdaki önerileri dikkate alması yararlı olabilecektir.

- Çalışma için seçilecek örgütsel yapının evreni en iyi temsil edecek en iyi örnek kütleden oluşuyor olmasina dikkat edilmelidir,

- Evren içinden seçilecek örneklem rastsal olarak seçilmelidir,

- Örnekleme uygulanacak olan anket ve diğer veri toplama araçlarının daha önce pilot uygulamalarının yapılmış olması veya hali hazırda kullanılmış ve pilot uygulaması yapılmış olan çalışmalarda kullanılmış veri toplama araçlarından yararlanması önem arz etmektedir.

- Uygulanacak veri toplama araçlarının etkinliğinin azalmaması için araştırmayı yapacak kişiler ile örneklemin aynı örgütten olmaması önem arz etmektedir.

\section{KAYNAKLAR}

Afşar: T. "Çalışma Yaşam Kalitesinin Örgütsel Bağll1ık Düzeyi Üzerindeki Etkisi: Devlet ve Vakıf Üniversitelerinde Çalışan Akademisyenler Üzerine Nicel Bir Araştırma (Yayımlanmamış doktora tezi) Hacettepe Üniversitesi Sosyal Bilimler Enstitüsü Sosyoloji Anabilim Dalı, 2011.

Akdemir, Yücel (2019). ISSMMO Seçimlerini Mevcut Oda Başkanı Yücel AKDEMIR'in Grubu Kazandı. https://www.muhasebenews.com/ismmmo-secimlerini-mevcut-oda-baskani-yucel-akdemirin-grubu-kazandi12-5-2019/ adresinden alındi.

Allen, N. J. \& Meyer, J. P. (1990). The MeasurementandAntecedents of Affective, Continuanceand Normative Commitmenttothe Organization. Journal of Occupational Psychology, 1-18.

Altınöz, M., Çöp. \& T. Sığındı (2011). Algılanan örgütsel bağllllk ve örgütsel sinizm ilişsisi: Ankara'daki dört ve beş yıldızlı konaklama işletmeleri üzerine bir araş̧ırma.SÜ İ̈BF Sosyal ve Ekonomik Araştırmalar Dergisi, 15(21), 285-315.

Arı, G., Ergeneli, A. (2003). Psikolojik Güçlendirme Algısı Ve Bazı Demografik Değişkenlerin Örgütsel Bağlllığa Etkisi. Hacettepe Üniversitesi İktisadi ve İdari Bilimler Fakültesi Dergisi, 2l(1), 129-149. Retrieved from https://dergipark.org.tr/en/pub/huniibf/issue/7882/103575

Aslan, Ş. (2008). Örgütsel Vatandaşlık Davranışı ile Örgütsel Bağlllık ve Mesleğe Bağlllık Arasındaki İlişkilerin Araştırllmasl. Yönetim ve Ekonomi Dergisi, 163-178.

Balay, R. (2000). Yönetici ve Öğretmenlerde Örgütsel Bağllllk. Nobel Yayın Dă̆ıtım. 
Başyiğit, A. (2006). Örgütsel İletişimin Örgütsel Bağlllık Üzerine Etkisi. Örgütsel İletişimin Örgütsel Bağllllk Üzerine Etkisi. Dumlupınar Üniversitesi Sosyal Bilimler Enstitüsü.

Barnes, L. (2010). The effects of organizational cynicism on community colleges: Exploring concepts from positıve psychology (Doctoral dissertation Available from ProOuest Dissertations and Theses database). UMI

Bernert, J. B., A. A. Armenakis, Hs S. Feild, ve H. J. Walker, (2007). Justice, cynicism, and commitment: study of important organizational change variables. The Journal of Applied Behavioral Science, 303-326.

Bozkurt, Ö., Yurt, İ. (2013). Akademisyenlerin Örgütsel Bağlllık Düzeylerini Belirlemeye Yönelik Bir Araşttrma. Yönetim Bilimleri Dergisi. 11(1), 121-139.

Çetin, M. (2004). Örgüt Kültürü ve Örgütsel Bağglllk. Nobel Yayınları.

Çetin, M. Ö. (2004). Örgütsel Vatandaşlık Davranışının Bazı Kavramlarla İlişkisi. Ankara: Nobel Yayın Dağıtım.

Çöl, G. (2004). Örgütsel Bağllllk Kavramı ve Benzer Kavramlarla İlişsisi. İnsan Kaynakları, 6(2). http://www.isguc.org/arc_view.php?ex=233 adresinden alınd1

Demir, C. \& Öztürk, U. C. (2011). Örgüt Kültürünün Örgütsel Bağlllı Üzerine Etkisi ve Bir Uygulama. İktisadi ve İdari Bilimler Fakültesi Dergisi, 26(1).

Doğan: \& Kılıç: (2007). Örgütsel Bağlllı̆ğn Sağlanmasında Personel Güçlendirmenin Yeri ve Önemi. Erciyes Üniversitesi İkt. ve İdari Bil. Fakültesi Dergisi, 37-61.

Erdoğan, İ. (1996). Örgütsel Davranış. İstanbul: İ.Ü. İşletme Fakültesi.Erdoğan, İ. (1996). Örgütsel Davranış İşletme Fakültesi.

Fındık, M. \& Eryeşil, K (2012). Örgütsel sinizmin örgütsel bağlllık üzerindeki etkisini belirlemeye yönelik bir araştırma." In 1. International Iron \& Steel Symposium (IISS). Karabük Üniversitesi Teknoloji Fakültesi, 2012. 250-255.

Gökburun, H. (2017). Örgütsel Bağlllık ve Banka Çalışanları: İstanbulda Bir Uygulama (Yüksek Lisans Tezi). Beykent Üniversitesi Sosyal Bilimler Enstitüsü.

İnce, M. \& Gül, H. (2005). Örgütsel Bağlllık Yönetimde Yeni Bir Paradigma. Ankara: Çizgi Kitapevi.

Kaya, O. (2007). Örgütsel Bağllllk Emniyet Genel Müdürlüğ̈̈ Merkez Biriminde Bir Uygulama. Yüksek Lisans Tezi. Ankara: Gazi Üniversitesi Sosyal Bilimler Enstitüsü.

Kılıç: (2013). Örnekleme Yöntemleri, Journal of Mood Disorders Volume: 3, Number: 1, ss.44-46.

Movday, R. Steers, R. \& Porter, L. (1979). The Measurement of Organizationa lCommitment. Journal of Vocational Behavior, 14.

Nafei, W. A. \& B. A. Kaifi. (2013). The Impact of Organizational Cynicism on Organizational Commitment: An Applied Study on Teaching Hospitals on Egypt. European Journal of Business and Management, 5(12), 131147.

Özsoy, Süheyla, A. Şafak Ergül \& Ayka Erkekik (2004). Bir Yüksekokul Çalışanlarının Örgüte Bağlılık Durumlarının İncelenmesi. Endüstri İlişkileri ve İnsan Kaynakları Dergisi, 6(2)

Wiener, Y. (1982). Commitment in Organization A NormativeView. Academy of Management Review, 7(3), 418428.

Yağc1, K. (2003). Toplam Kalite Yönetimi Kapsaminda Meyer-Allen Örgütsel Bağlllık Modeli ve Otel İşletmeleri Uygulaması (Yüksek Lisans Tezi). Dokuz Eylül Üniversitesi Sosyal Bilimler Enstitüsü. 